\title{
«Revolutionary change in technology» must be translated into labour law
}

Kitty Malherbe, Kgomotso Mokoena and Darcy du Toit

\section{(2) OpenEdition}

1 Journals

\section{Electronic version}

URL: https://journals.openedition.org/rdctss/1418

DOI: $10.4000 /$ rdctss. 1418

ISSN: 2262-9815

\section{Publisher}

Centre de droit comparé du travail et de la sécurité sociale

\section{Printed version}

Date of publication: 1 December 2019

Number of pages: 182-189

ISSN: $2117-4350$

\section{Electronic reference}

Kitty Malherbe, Kgomotso Mokoena and Darcy du Toit, "«Revolutionary change in technology» must be translated into labour law", Revue de droit comparé du travail et de la sécurité sociale [Online], 4 | 2019, Online since 01 November 2021, connection on 11 November 2021. URL: http://

journals.openedition.org/rdctss/1418; DOI: https://doi.org/10.4000/rdctss.1418

\section{(c) (i) $\odot$}

Revue de droit comparé du travail et de la sécurité sociale est mise à disposition selon les termes de la Licence Creative Commons Attribution - Pas d'Utilisation Commerciale - Pas de Modification 4.0 International. 


\section{«REVOLUTIONARY CHANGE IN TECHNOLOGY» MUST BE TRANSLATED INTO LABOUR LAW}

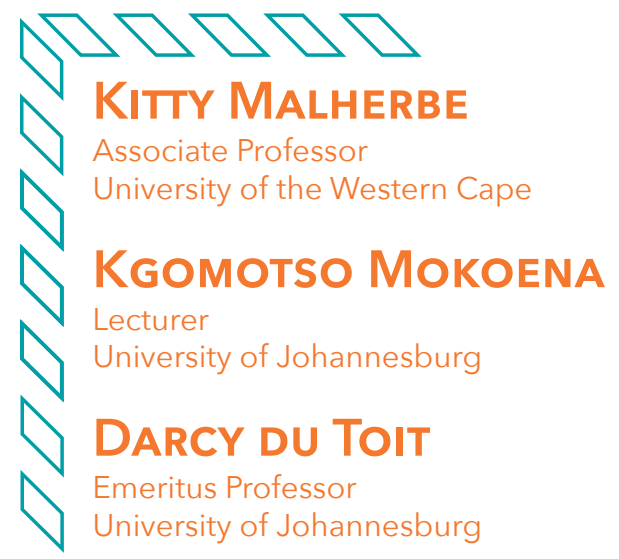

n his speech at the opening of Parliament in February 2019, South African President Cyril Ramaphosa remarked: «Our greatest challenge is to create jobs for the unemployed of today, while preparing workers for the jobs of tomorrow ... The world we now inhabit is changing at a pace and in a manner that is unprecedented in human history. Revolutionary advances in technology are reshaping the way people work and live. They are transforming the way people relate to each other, the way societies function and the way they are governed ${ }^{1}$.

These observations are highly relevant to the South African labour market which, like labour markets elsewhere, has been challenged by globalisation and technological innovation, disrupting long-standing systems and standards in many sectors. In addition, factors such as a persistently high unemployment rate ${ }^{2}$, and a relatively high incidence of informal and precarious work, complicate the impact of the digital revolution on the country.

1 State of the Nation Address, 7 February 2019: https://www.gov.za/speeches/presidentcyril-ramaphosa-2019-state-nation-address-7-feb-2019-0000

2 According to Statistics SA, the latest unemployment rate was 27.5\%: Quarterly Labour Force Survey third quarter 2018. 
Part of this process has been the introduction of innovative business models collectively referred to as the "sharing economy» or "platform economy», consisting of online applications (apps) which - in theory - allow individuals to mobilise their dormant assets to make a profit ${ }^{3}$. In practice, platform-based enterprises insert themselves into the equation by connecting consumers to services or products ${ }^{4}$. The effect is that consumers contract with the platform and the platform engages workers to deliver the service or product. Uber Technologies Inc. is an exemplar of this type of business. It is at the centre of a ridesharing, food delivery and transportation network which operates in hundreds of cities worldwide, using its app to connect riders with drivers (also known as «partners»). In South Africa it exists as Uber South Africa Technology Services (Pty) Ltd, an affiliate of Uber International Holding B.V. in Amsterdam - but partners' contracts are with Uber B.V., also in Amsterdam. The term «Uber» refers to the integrated operation. But its business model has faced increasing legal challenges in different countries.

Uber's profitability depends to a significant extent on classifying its drivers as independent contractors rather than employees; its contracts say so repeatedly, emphasising that it is not running a transport business but is only leasing an app. Its income, however, comes from fares generated by drivers. These fall into two categories. First, there are drivers who own the vehicles which they drive, known as "partners». More common in South Africa, however, are «drivers-only» who, in most cases, lease their vehicles from partners («fleet owners») - an arrangement actively facilitated by Uber ${ }^{5}$. But, in Uber's contractual model, all its "partners» are «businesses which provide transportation services» while Uber merely provides the app 6 .

The implications for the labour market are huge. As the Labour Court put it in Uber South Africa Technology Services (Pty) Ltd v NUPSAW \& others ${ }^{7}:$ "[t] the nature of the engagement of drivers who use the Uber App (and indeed the many others who provide services in what has been described as the "gig economy") poses a challenge to traditional conceptions of employment worldwide, and has tested the boundaries of the protection extended to working people by domestic labour legislation» ${ }^{8}$.

3 I.M. Giuli and I. Maselli, Uber: Innovation or déjà vu: https://www.ceps.eu/system/files/COMUBERM GandIM.pdf

4 E. Isaac, "Disruptive Innovation: Risk Shifting and Precarity in the Age of Uber», Working Paper 2014-7, Berkeley Roundtable on the International Economy, 2.

5 https://www.fin24.com/Tech/News/over-600-cars-leased-through-uber-wesbank-deal-20160901. For more on the distinction between "partners», "partner-drivers» and "drivers» in the Uber business model, see Uber SA v NUPSAW (2018) 39 ILJ 903 (LC), paras 22-24.

6 Uber User Terms: https://www.uber.com/legal/zaf/terms. By 2017 there were more than 12000 drivers and 969000 riders registered on Uber's app in South Africa: «Uber reaches almost 1-million users in South Africa»: http://www.engineeringnews.co.za/article/uber-reaches-almost-1-millionusers-in-sa-2017-11-09

7 (2018) 39 ILJ 903 (LC). See, further, K. Mokoena, «Are Uber Drivers Employees? A Look at Emerging Business Models and Whether they Can be Accommodated by South African Labour Law», ILJ, 37 (2016), p. 1574.

8 Uber SA v NUPSAW, para. 2. 


\section{I - ROUND ONE TO UBER}

Here it is necessary to take a step back. This case, the first of its kind in South Africa, began when several drivers who had been "deactivated" by Uber ${ }^{9}$ for one reason or another, approached the Commission for Conciliation, Arbitration and Mediation (CCMA), a quasi-judicial labour dispute-resolution forum, to institute unfair dismissal disputes against «Uber» ${ }^{10}$. However, Uber's formidable legal team raised some preliminary questions. First, which Uber company was the claim against? Uber BV and Uber SA argued that Uber SA was the intended respondent. The drivers did not know any better and that became a fact. Secondly, the CCMA has jurisdiction only over disputes initiated by «employees» as defined in the Labour Relations Act of 1995 (LRA). Uber SA accordingly objected to the jurisdiction of the CCMA on the basis that the drivers were not employees, neither of Uber BV (with which partners have their contracts), let alone Uber SA, which does not formally enter into contracts with partners or drivers ${ }^{11}$.

The commissioner used a "generous» interpretation of the definition of «employee», in light of the Constitution and the "Code of Good Practice: Who is an employee?», to rule that the drivers were employees of Uber SA. She held that the drivers' «real» relationship was with Uber SA which appointed, approved and controlled the drivers, while the relationship with Uber BV was «distant and anonymized», indicating that Uber SA was the real employer ${ }^{12}$.

The commissioner's ruling was referred by Uber for review by the Labour Court ${ }^{13}$. By now the drivers had legal representation, and an application to join Uber BV to the proceedings was dismissed on technical grounds - a fact which was to play a decisive part in the court's judgment ${ }^{14}$. For it meant that the court proceeded to consider the matter solely in relation to Uber SA and disregarded the role of Uber BV, since it was not a party to the proceedings.

9 I.e., had their access to the app unilaterally cancelled.

10 Uber South Africa Technological Services (Pty) Ltd and NUPSAW and SATAWU obo Morekure \& others, Case no. WECT 1253716, 7 July 2017.

11 Para. 24.

12 Para. 50.

13 Uber South Africa Technology Services (Pty) Ltd v National Union of Public Service and Allied Workers (NUPSAW) and Others (2018) 39 ILJ 903 (LC).

14 Para. 15. 
On this basis, the court assessed the facts more narrowly than the CCMA had done, focusing exclusively on the role of Uber SA. In particular, it found that:

- the drivers were not screened or appointed by Uber SA but by Uber BV;

- the on-boarding process (whereby drivers' details are loaded onto the app) was concluded by Uber BV, not Uber SA;

- technology owned and operated by Uber BV facilitated the payment of drivers;

- this payment emanated from a local non-resident bank account under the name «Uber BV South Africa» ${ }^{15}$;

- it was Uber BV, not Uber SA, that set maximum fare tariffs, price cuts and income guarantees; - the supervisory role of Uber BV could not be ascribed to Uber SA, as all control functions are exercised through the app ${ }^{16}$.

In South Africa, as in many countries, «employees» are distinguished from «independent contractors» by weighing up factors which are typical of employment against those which point at self-employment. In making the above assessment, J. Van Niekerk thus ascribed many of the factors indicative of a possible employment relationship to Uber BV as opposed to Uber SA, and on this basis concluded that there was no employment relationship between the drivers and Uber SA. However, he expressly made no finding on whether the drivers are employees of Uber BV, or whether they are independent contractors of Uber BV, as it was not the issue before the court ${ }^{17}$.

In a subsequent case ${ }^{18}$, a driver seeking a remedy for unfair dismissal in the CCMA cited not only Uber SA as the alleged employer but also Uber BV, since - as found by the court in Uber $v$ NUPSAW (above) - this is the party with which all Uber partners contract and by whom all drivers are controlled. To the surprise of many, the CCMA commissioner ruled that the CCMA did not have jurisdiction to hear the matter because Uber BV has its registered office in the Netherlands ${ }^{19}$. From this the commissioner concluded that the dispute must be subject to Dutch law and, therefore, beyond the reach of the LRA. Furthermore, a clause in the agreement that drivers enter into with Uber BV stipulates that disputes between drivers and Uber BV are to be settled by arbitration in the Netherlands according to Dutch law. The CCMA therefore washed its hands of the matter.

15 Para. 89.

16 For example, it was not disputed that the «sub-Saharan deactivation policy», used when deactivating users from the app, was developed and implemented by Uber BV and not Uber SA: para. 91.

17 Para. 99.

18 NUPSAW obo Mostert $v$ Uber South Africa Technology Services (Pty) Ltd \& others, Case no. WECT18234-18, 31 May 2018. A subsequent unopposed CCMA ruling against Uber, Ngalonkulu $\checkmark$ Uber [2018] 9 BALR 1020 (CCMA), was rescinded.

19 Mostert v Uber, para. 18. 
It is difficult to imagine that this ruling could have been upheld on review, let alone by a higher court. As the European Court of Justice recently held, Uber's business is «a service in the field of transport» ${ }^{20}$. Also in South Africa it can be argued that Uber is a passenger transport business and, as such, its business is not merely leasing its app to drivers and riders from Amsterdam. Crucially, its business depends on drivers transporting passengers in Cape Town and elsewhere under the Uber brand.

Not only is the CCMA ruling logically questionable, it is also at odds with public policy and social justice. It implies that the applicant or any other driver wishing to challenge Uber must go to the Netherlands to have their dispute heard, presumably instructing Dutch counsel. This very proposition was recently rejected in the strongest possible terms by the Ontario Court of Appeal in Heller v. Uber Technologies Inc ${ }^{21}$, where Uber sought to rely on a similar clause to prevent drivers from bringing a class action against it in Canada. The court noted that the administrative costs alone of the legal process prescribed in Uber's contract with drivers would come to $C \$ 14500$ - that is, exclusive of legal fees, travel and accommodation - whereas the appellant earned between $C \$ 20,800$ and $C \$ 31,200$ per year before tax and expenses. Not surprisingly, the court ruled that the arbitration clause was «unconscionable» and without legal effect.

Also in South Africa, freedom of contract is not unlimited and contracts are subject to constitutional scrutiny. The courts must, as the Supreme Court of Appeal has put it, "achieve a balance that strikes down the unacceptable excesses of "freedom of contract", while seeking to permit individuals the dignity and autonomy of regulating their own lives» ${ }^{22}$. The Constitutional Court upheld this judgment, emphasising that contractual terms will be null and void if they are against public policy and that, in answering this question, it is necessary to consider «the relative situation of the contracting parties». This, it was held, is «a recognition of the potential injustice that may be caused by inequality of bargaining power» ${ }^{23}$.

There can be no doubt that Uber's overwhelming bargaining power over drivers weighs heavily against any notion that the arbitration clause in Uber's contracts with drivers is a true expression of freedom of contract or that the impossible burden it places on drivers, effectively denying them access to justice, is in accordance with public policy.

20 Asociación Profesional Elite Taxi v Uber Systems Spain SL Court of Justice of the European Union 20 December 2017 ECLI:EU:C:2017:981, para. 48.

21 (2019) ONCA 1.

22 Napierv Barkhuizen 2006 (9) BCLR 1011 (SCA), paras 12-13.

23 Barkhuizen v. Napier 2007 (7) BCLR 691 (CC), para. 59. 


\section{II - TOWARDS A NEW REGULATORY MODEL}

New phenomena call for new responses. The discussion so far shows that South African case law has remained locked into the Roman Law dichotomy between «employees» and «independent contractors» in seeking to unscramble the (mis)classification of Uber drivers. In this it has followed the same pattern as in other jurisdictions, focusing on a common doctrinal issue - whether the workers in the platform economy have the status of employees or independent contractors - to determine workers' rights ${ }^{24}$.

The litigation has gone different ways in different countries. In the USA, courts in several states have upheld Uber's contention that the drivers are independent contractors. In the UK, on the other hand, the Court of Appeal recently held that the drivers are "workers» and therefore entitled to minimum wages and paid holidays in terms of the Employment Rights Act (ERA) ${ }^{25}$. This finding, however, was informed by the UK regulatory framework, in terms of which Uber can only operate in London by obtaining a license to provide transport services. This license was issued to Uber London Ltd (ULL), and drivers must contract with ULL in order to earn a living. This created a ready basis for inferring a worker-employer relationship between drivers and ULL. In countries where drivers can obtain licenses individually - as in South Africa - Uber's corporate smokescreen is more difficult to penetrate.

Having said that, should the classification of workers in the platform economy really be the only question, or the key question, in the context of rapidly evolving business models and new forms of work?

There are several reasons for suggesting that the answer must be «no». On the one hand, if a South African court were to rule (in the hopefully not too distant future) that Uber drivers are indeed employees, it would be cause for celebration. It would have a knock-on effect on the regulation of organisation in the transport industry, giving drivers the right to engage in collective bargaining, protection against unfair dismissal and unfair labour practices, and access to certain kinds of social security. These would be highly significant gains. On the other hand, the impact would be limited to Uber drivers and other workers in the platform economy with similar contractual arrangements with platforms. Workers in the platform economy are a heterogeneous group ${ }^{26}$; some, like Uber drivers, are deployed by technology to perform tasks in the real world, while crowdworkers perform their work wholly in cyberspace. A victory for one group will not necessarily translate into a victory for all.

24 See M Cherry «Beyond misclassification: The digital transformation of work», CLLPJ, 37 (2016), p. 578.

25 ERA distinguishes between «employees», who are employed in terms of a contract of employment, and «workers» who is employed under a contract to provide personal services (i.e., not an employment contract) to another party who is not a client or a customer. Workers are entitled to limited protection under ERA.

26 V. De Stefano, "The rise of the "just-in-time workforce": On-demand work, crowdwork, and labor protection in the "gig-economy"», CLLPJ, 37 (2016), p. 471. 
The real lesson of the Uber cases in South Africa and internationally, it is suggested, is that labour law in a digital age should adapt to an environment where new forms of work are being created "which are much less capable of being recognised by more traditional modes or patterns of labour law ${ }^{27}$. Control over workers can be exercised via an intermediary or by algorithms, which does not easily accommodate communication with an actual supervisor or requirements of procedural fairness ${ }^{28}$. Rapid developments in technology and new forms of work may mean that the traditional stratagem of "extending» the reach of labour legislation to new categories of workers by statutory amendments will have limited effect: platform owners will continuously seek new ways of placing their working arrangements beyond the reach of legislation, while labour law tries to catch up with new forms of work for which it was not designed ${ }^{29}$. New ways of regulating supervision and control of workers, as well as the implementation of workers' basic rights, are required.

There is an even bigger picture. Platform work is inseparable from the broader trends in the labour market towards non-standard work (agency work, temporary work, zero-hour contracts and the like) that have unfolded since the 1980s, and shares many attributes with other forms of non-standard work ${ }^{30}$. The debate on labour and social protection for workers in the platform economy is part and parcel of the ongoing effort to improve protection of non-standard workers and regulation of non-standard work in the broader sense. In both cases the challenge is to design new mechanisms which can serve the same purposes in the world of non-standard work as individual worker rights, organisational rights, the right to bargain collectively and other institutions embodied in the LRA have served in the world of standard work.

Yet the reality is that many platform corporations and others benefit from the status quo. Uber's huge profitability would not have been the same if every driver in every city commanded the full cost of employment. Whether and how the development of a new framework giving non-standard workers equivalent rights takes place will depend on the political will of government and proponents of progressive change in the face of resistance by entrenched interests.

27 F. Hendrickx, "Regulating new ways of working: From the new "wow" to the new "how"», ELLJ, 9 (2018), p. 197.

28 Cherry 597 and 600.

29 D. du Toit, Labour Relations Law, LexisNexis, 2015 (69 highlight that amendments to labour legislation can be a protracted process).

30 V. De Stefano, op. cit., p. 499. 


\section{SOUTH AFRICA}

But, in the end, short-term business prospects cannot prevail over longer-term social need. There is evidence of a realisation that radical and significant change is required in President Ramaphosa's speech quoted at the beginning of this article, which continues: "[W]e are faced with a stark choice. It is a choice between being overtaken by technological change or harnessing it to serve our developmental aspirations. It is a choice between entrenching inequality or creating shared prosperity through innovation. Unless we adapt, unless we understand the nature of the profound change that is reshaping our world, and unless we readily embrace the opportunities it presents, the promise of our nation's birth will forever remain unfulfilled. Today, we choose to be a nation that is reaching into the future» ${ }^{31}$.

31 State of the National Address, 7 February 2019. 